\title{
O transplante de células-tronco hematopoéticas alogênico e autogênico na leucemia mielóide aguda em primeira remissão completa: análise de 62 pacientes Allogeneic and autologous hematopoietic stem cell transplantation in acute myeloid leukemia in first complete remission: analyses of 62 patients
}

\author{
Nadjanara D. Bueno \\ Orientador: Frederico L. Dulley
}

\section{Resumo}

Sessenta e dois pacientes consecutivos portadores de leucemia mielóide aguda submetidos a transplante alogênico e autogênico de células tronco hematopoéticas foram selecionados entre 1989 e 2006. O objetivo deste estudo foi analisar a sobrevida dos mesmos, sendo que $53,2 \%$ estavam vivos ao final do estudo, no transplante alogênico $43,3 \%$ e no transplante autogênico $62,5 \%$. Fatores como sexo, classificação Franco-Americano-Britânico, análise citogenética, tratamento de indução, regime de condicionamento e remissão após o primeiro ciclo de indução não tiveram impacto na sobrevida. A consolidação intensiva com altas doses de arabinosídeo resultou em melhora na sobrevida, com um $p$ significante de 0,0035 no transplante alogênico. A presença de doença do enxerto contra o hospedeiro aguda teve impacto na sobrevida dos pacientes, sendo que os que a tiveram em grau II tiveram melhor sobrevida em relação à ausência da mesma, grau I e III com um $p=0,0377$. Diarréia teve significância estatística na forma moderada no transplante alogênico. A doença do enxerto contra o hospedeiro crônica teve impacto na sobrevida, e dois pacientes que a tiveram na forma extensa morreram $(p=0,0008)$. Infecção foi à causa de óbito mais freqüente no transplante alogênico (41,1\% dos óbitos) seguida de recidiva $(29,4 \%$ dos óbitos). No transplante autogênico, a recidiva foi a principal causa de óbito ( $91,7 \%$ dos óbitos). Morte por toxicidade relacionada ao procedimento ocorreu em $47 \%$ dos pacientes, que foram a óbito no transplante alogênico e em $8,3 \%$ no transplante autogênico. $\mathrm{Na}$ analise univariada de Cox para fatores prognósticos, tiveram significância o tipo de leucemia mielóide aguda pela classificação FAB, análise citogenética, consolidação intensiva e DECH crônica ( $p=0,019, p=0,017, p=0,009$ e $p=0,018$ ). Na análise múltipla, consolidação intensiva e DECH crônica permaneciam com significância $(p=0,024)$.
Palavras-chave: Transplante de células-tronco hematopoéticas; Transplante homólogo/estatística \& dados numéricos; Transplante autólogo/estatística \& dados numéricos; Leucemia mielocítica aguda/mortalidade; Toxicidade de drogas/mortalidade; Doença enxerto-hospedeiro/mortalidade

\section{Summary}

Sixty-two consecutive patients with acute myeloid leukemia in first complete remission were submitted to allogeneic or autologous hematopoietic stem cell transplantation between 1989 and 2006. The objective of this study was to analyze the survival of patients, with $53.2 \%$ surviving at the end of the study: $43.3 \%$ after allogeneic and $65.2 \%$ after autologous transplantation. Factors such as gender, the French-American-British classification, cytogenetic analysis, induction therapy, remission after the first induction cycle of chemotherapy and conditioning regime did not have any impact on survival. Patients submitted to allogeneic transplantations who were consolidated with high doses of arabinoside had better survival with a $p$-value $=0.0035$. Acute graft-versus-host disease (GvHD) had an impact on survival; patients with Grade II had a better survival rate than those without or with Grades I and III GvHD giving a p-value of 0.0377 . Moderate diarrhea had statistical significance in allogeneic transplant. Chronic GvHD had an impact on survival with two patients who had severe chronic GvHD, dying ( $p=0.0008)$. Infection was the most frequent cause of death in allogeneic transplantation $(41.1 \%$ of deaths) followed by relapse $(29.4 \%$ of deaths). In autologous transplantation, relapse was the principal cause of death $(91.7 \%$ of deaths). Procedure-related toxicity occurred in $47 \%$ of patients who died in allogeneic and $8.3 \%$ in

Médica hematologista. Tese de mestrado defendida para obtenção do título de doutor em Ciências Médicas pela FMUSP.

Correspondência: Nadjanara Dorna Bueno

Hospital das Clínicas da Faculdade de Medicina da Universidade de São Paulo

Av. João Ramalho, $n^{\circ} 148$ apto 32 - Centro

09030-320 - Santo André-SP

E-mail:nadjanaradb@ig.com.br 
autologous transplantations. Univariate Cox analysis of the prognostic factors showed significance for the type of leukemia according to the FAB classification, cytogenetics analysis, intensive consolidation and chronic GvHD ( $p=0.019, p=0.017$, $\mathrm{p}=0.009$ and $\mathrm{p}=0.018$, respectively). In multivariate analysis, intensive consolidation together with chronic GvHD had significance with a $\mathrm{p}=0.0244$.

Key Words: Hematopoietic stem cell transplantation; Transplantation, homologous/statistics \& numerical data; Transplantation, autologous / statistics \& numerical data; Leukemia myelocytic, acute/mortality; Drug toxicity/mortality; Graft vs. host disease /mortality.

Avaliação: A Revista Brasileira de Hematologia e Hemoterapia publica os resumos e abstracts de teses da área apresentados em entidades que tenham programas de pós-graduação reconhecidos pelo MEC/Capes e considera a obtenção do título suficiente para sua publicação na forma como se propõe a seção.

Recebido: $11 / 04 / 2008$

Aceito: 14/04/2008 